Journal of Clinical Investigation

Vol. 41, No. 3, 1962

\title{
THE NONHEMOGLOBIN ERYTHROCYTIC PROTEINS, STUDIED BY ELECTROPHORESIS ON STARCH GEL *
}

\author{
By A. HAUT, $\nmid$ G. R. TUDHOPE $\ddagger$ G. E. CARTWRIGHT ANd M. M. WINTROBE \\ (From the Department of Medicine, University of Utah College of Medicine, \\ Salt Lake City, Utah)
}

(Submitted for publication July 10, 1961 ; accepted September 18, 1961)

In the investigation of the electrophoretic behavior of hemolysates, attention has usually been limited to study of the normal and abnormal hemoglobins and little if any note has been taken of the nonhemoglobin protein (NHP) constituents. However, NHP fractions have been detected by electrophoresis of hemolysates from normal subjects, employing the procedure of Tiselius $(1,2)$ or zone electrophoresis on paper (3), starch block (4), starch gel (5-7), and agar (8). Although some NHP fractions have been reported to be separable by column chromatography (9), the latter technic is difficult and time consuming and does not serve well as a simple screening procedure.

In this report the separation of six NHP erythrocytic constituents by a new modification of the starch-gel electrophoretic technic of Smithies $(10,11)$ will be described. The principal constituent of each of two of the NHP zones has been identified and certain characteristics of the other zones will be presented. The difference between the patterns of NHP derived from the blood of normal adult subjects and healthy newborn infants will be described. A preliminary report of this work has been presented (12). ${ }^{1}$

\section{METHODS}

Preparation of hemolysates. Washed red cells were hemolyzed by freezing and thawing. After the addition of 0.5 vol of distilled water and treatment with toluene as described by Drabkin (13), the resultant hemolysate was clarified by centrifugation at $15,000 \mathrm{G}$ and the hemoglobin concentration reduced to $14 \mathrm{~g}$ per $100 \mathrm{ml}$.

* This investigation was supported by Research Grant A-4489 from the National Institute of Arthritis and Metabolic Diseases, Bethesda, Md.

$\uparrow$ Markle Scholar in Medical Science.

$\ddagger$ Lederle Traveling Fellow; on leave from the Department of Pharmacology and Therapeutics, University of Sheffield, 1959-60.

1 The terminology assigned to the NHP in the preliminary report differs from that used here.
Buffer system. The gels were made with $0.074 \mathrm{M}$ Tris adjusted to $\mathrm{pH} 9.5$ with 10 per cent citric acid. The electrode and bridge vessels contained $0.1 \mathrm{M}$ boric acid adjusted to $\mathrm{pH} 9.5$ with $2 \mathrm{~N}$ sodium hydroxide.

These buffers were found to give the most satisfactory results in preliminary experiments in which different buffers, of various concentrations and $\mathrm{pH}$, were studied. Sharper separations were obtained with the "discontinuous" buffer system of Tris and citric acid in conjunction with a borate bridge buffer $(14,15)$ than with either borate or Tris alone or Tris-EDTA-borate $(16,17)$.

To determine whether the use of a buffer at $\mathrm{pH} 9.5$ modified the native proteins, a hemolysate was equilibrated for 18 hours with Tris-citrate buffer at $\mathrm{pH} 9.5$, then dialyzed against the same buffer adjusted to $\mathrm{pH} 8.6$ prior to electrophoresis at $\mathrm{pH}$ 8.6. A portion of the same hemolysate, kept aside as a control and not exposed to the buffer of $\mathrm{pH} 9.5$, was subjected to electrophoresis on the same gel. Identical zones were obtained with both portions of the hemolysate, whether or not it was exposed to the higher $\mathrm{pH}$. However, not all of the NHP zones were separated at $\mathrm{pH}$ 8.6.

Preparation of gel and electrophoresis. Hydrolyzed starch, either prepared by the authors as described by Smithies (10) or purchased (Connaught Medical Research Labs., Toronto, Canada), was suitable. Best results were obtained with gels that were prepared with 13.6 to $14.1 \mathrm{~g}$ of starch per $100 \mathrm{ml}$ buffer solution, depending upon the individual lot. Concentrations of starch of 12 to $13 \mathrm{~g}$ per $100 \mathrm{ml}$, which are suitable for serum electrophoresis, were not satisfactory for this study.

With the modifications in starch concentration and composition of the buffers noted above, the gel was prepared as described by Smithies and electrophoresis was carried out in a vertical plane (11) with the anode lowermost, at $6^{\circ} \mathrm{C}$, with a voltage gradient of $8.5 \mathrm{v}$ per $\mathrm{cm}$, for about 18 hours.

Staining of the gel. The gel was bisected by a cut parallel to its broadest surface. This yielded a pair of surfaces from the interior of the gel for study, one the mirror image of the other. One half of the bisected gel was stained for protein with amido-black 10B (10). The other half was first overlaid with 3 per cent hydrogen peroxide to localize catalase activity and then, after flushing with distilled water, with a reagent to localize hemin. The latter reagent was freshly prepared by combining: $50 \mathrm{ml}$ methanol saturated with benzidine hydrochloride, $10 \mathrm{mg}$ sodium nitroferricyanide freshly dissolved in $50 \mathrm{ml}$ distilled water, $10 \mathrm{ml}$ glacial acetic acid, and 3 


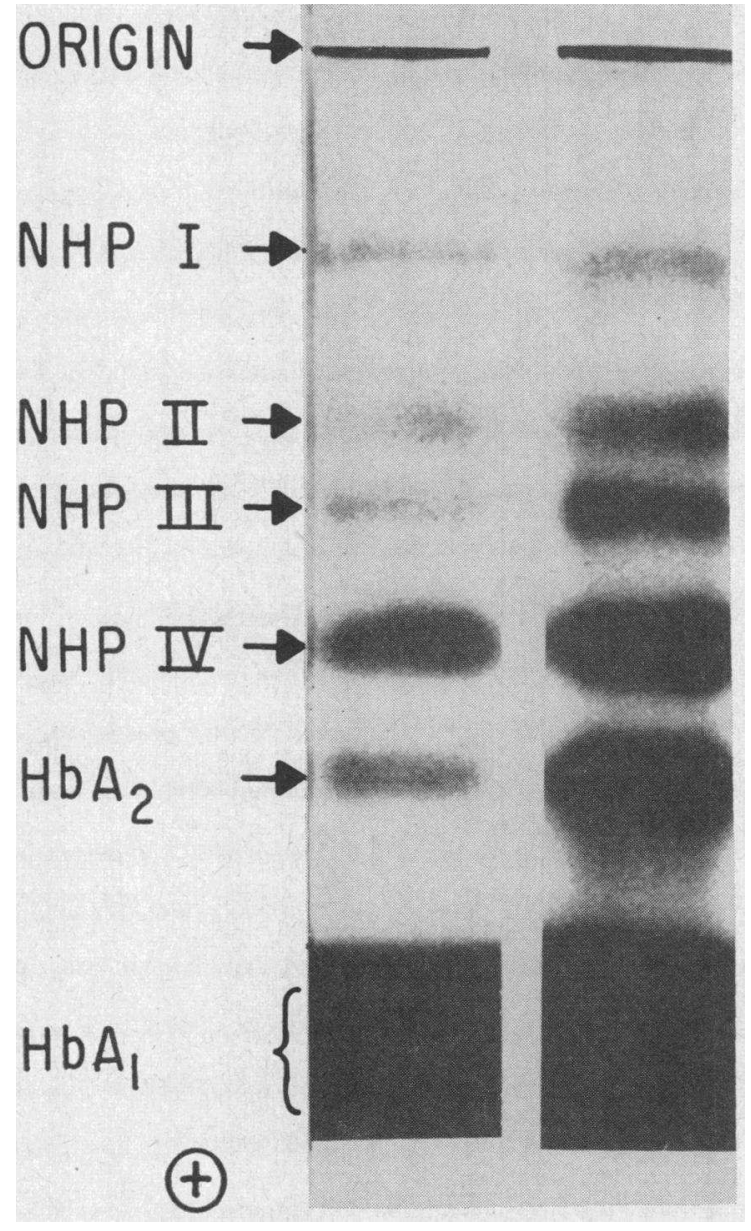

Fig. 1. Electrophoresis of hemolysate from NORMaL ADULT SUBJECT; AMIDO-BLACK STAIN. Four nonhemoglobin protein zones (NHP) and two hemoglobin $(\mathrm{Hb})$ zones are illustrated; NHP zones Ia and IIa, sometimes separated in addition to those shown here, would be cathodal to NHP I and II, respectively. The relative intensity of the staining of the zones is not accurately depicted owing to the high contrast properties of the photographic materials employed. To help illustrate the relative staining and width of the zones, the hemolysate used in the track on the left had less than the standard hemoglobin concentration.

ml 3 per cent hydrogen peroxide. The nitroferricyanide rendered the hemin-containing zones a deep black color which persisted, whereas the color developed by benzidine alone faded rapidly.

Carboxymethyl cellulose was prepared for adsorption of hemoglobin as described by Huisman and Meyering (18). Diethylaminoethyl cellulose was treated as described by Hennessey, Haffner and Gabrio (19). IRC-50 was prepared by the method of Allen, Schroeder and Balog (20). Catalase assays were performed as described by Takahara and co-workers (21) except that assays were performed at $20^{\circ}$ rather than $37^{\circ} \mathrm{C}$. Carbonic anhydrase assays were performed by the method of Wilbur and Anderson (22). The "S protein" was prepared by the method of Moskowitz, Dandliker, Calvin and Evans (23). The alkaline resistant fraction of hemolysates was prepared by the method of Derrien, Laurent and Roques (24). Chloroform-ethanol fractionation was based on the method of Tsuchihashi (25) as modified by Huennekens, Liu, Myers and Gabrio (26).

Photographic records. Photographic records of stained gels were made on $35 \mathrm{~mm}$ Kodak Microfile film, with tungsten illumination and a red filter, and were developed in Kodak D-11.

\section{RESULTS}

Normal pattern. In the unstained gels the NHP zones were colorless. The major adult hemoglobin, $A_{1}$, and the normal minor component, $\mathrm{A}_{2}$, described by Kunkel, Ceppellini, Müller-Eberhard and Wolf (4) could be recognized by their characteristic color. After staining the gels with amido-black, four distinct zones of lesser anodal mobility than the hemoglobins were revealed (Figure 1). These were termed NHP zones I, II, III, and IV, in order from the origin. Two additional NHP zones, narrow and staining

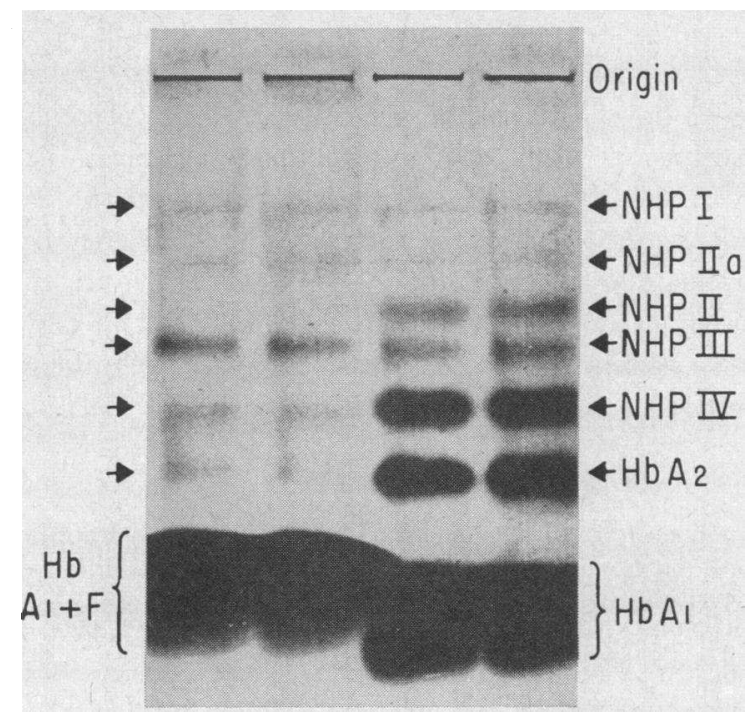

Fig. 2. EleCtROPHORESIS OF HEMOLYSATES FROM NORMAL ADULT AND NEWBORN SUBJECTS; AMIDO-BLACK STAIN. Hemolysates from two normal adult subjects (right) are compared with hemolysates from two newborn subjects (left). In an anodal direction from the origin slits, NHP zones I, IIa, II, III, and IV can be seen in the adults. In the newborn, NHP II is virtually absent and NHP IV considerably reduced. $\mathrm{Hb} \mathrm{F}$, present in addition to $\mathrm{Hb}$ $\mathrm{A}$, in the newborn, has produced retardation of the main hemoglobin zone. $\mathrm{Hb} \mathrm{A} \mathrm{A}_{2}$ is reduced in the newborn. 
TABLE I

Characteristics of protein zones separated by electrophoresis on starch gel

\begin{tabular}{|c|c|c|c|c|c|}
\hline $\begin{array}{l}\text { Protein } \\
\text { zone }\end{array}$ & $\underset{\text { migration* }}{\text { Relative }}$ & $\begin{array}{l}\text { Width } \\
\text { of zone }\end{array}$ & $\begin{array}{l}\text { Intensity of } \\
\text { staining with } \\
\text { amido-black }\end{array}$ & $\begin{array}{l}\text { Benzidine } \\
\text { reaction }\end{array}$ & $\begin{array}{c}\text { Gas pro- } \\
\text { duction } \\
\text { with } \mathrm{H}_{2} \mathrm{O}_{2}\end{array}$ \\
\hline I & $\begin{array}{c}0.29 \\
( \pm 0.032)\end{array}$ & + & ++ & 0 & 0 \\
\hline II & $\begin{array}{c}0.47 \\
( \pm 0.029)\end{array}$ & ++ & ++ & 0 & 0 \\
\hline III & $\begin{array}{l}0.57 \\
( \pm 0.040)\end{array}$ & ++ & + & + & $+t+$ \\
\hline IV & $\begin{array}{c}0.69 \\
( \pm 0.016)\end{array}$ & +++ & +++ & 0 & 0 \\
\hline $\mathrm{A}_{2}$ & $\begin{array}{c}0.82 \\
( \pm 0.018)\end{array}$ & $+t+$ & $++t$ & +++ & 0 \\
\hline$A_{1}$ & 1.00 & ++++ & ++++ & +++ & 0 \\
\hline
\end{tabular}

* Relative migration calculated from measurements of the zones in 164 tracks on 25 gels (see text); mean, \pm SD.

rather lightly, were seen on some gels cathodal to zones I and II and were termed Ia and IIa, respectively.

Each of the four principal NHP zones could be identified by considering five characteristics: 1) relative migration from the origin, 2) intensity of staining with amido-black, 3) width of the stained band, 4) reaction with dilute hydrogen peroxide, and 5) reaction with the benzidinenitroprusside reagent (Table I and Figures 1, $2,3)$.

These five characteristics have been studied in hemolysates prepared from more than 50 normal adult subjects. A uniform pattern was noted. The results in 164 tracks on 25 gels are summarized in Table I. No significant variation occurred when 10 different hemolysates were prepared from the same subject over a period of 5 months.

The relative migration was calculated as the ratio of the distance from the origin to the center of the zone under consideration (numerator) divided by the distance from the origin to the sharp cathodal edge of the broad $A_{1}$ zone (denominator). The relative migration of each zone was rather constant, the values in Table I indicating a coefficient of variation of 11 per cent for NHP zone I, 6 to 7 per cent for zones II and III, and about 2 per cent for NHP zone IV and the $A_{2}$ zone.

Zone IV was the widest, zone I, the narrowest; zones II and III were equal and intermediate in width between zones I and IV. In regard to the intensity of staining with amido-black, zone IV stained most intensely and zone III the least intensely. Zones I and II stained equally and were intermediate in intensity between zones III and IV.

Only zone III of the NHP zones reacted with the benzidine-nitroprusside reagent (Figure 3 ). The color development was neither so intense nor so rapid as with the two hemoglobin zones.

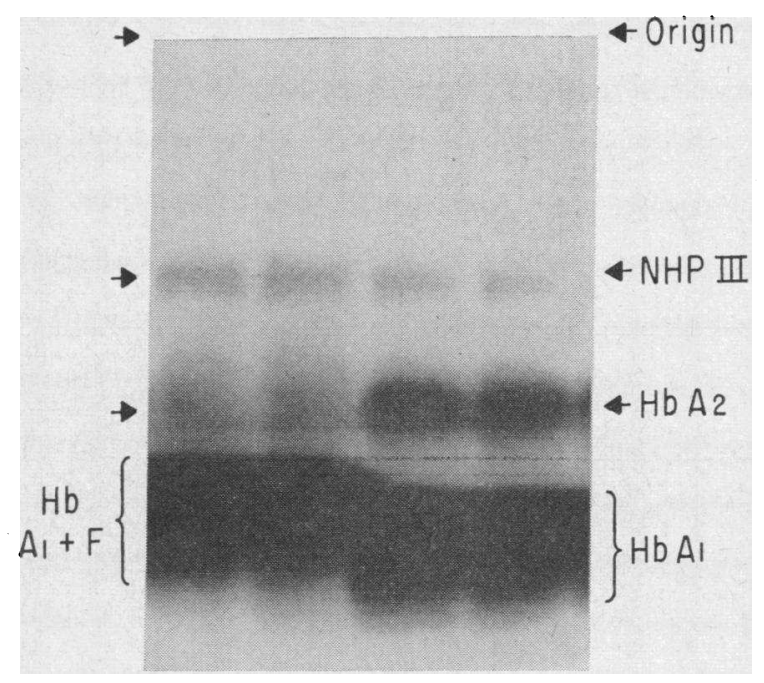

Fig. 3. ElECTROPHORESIS OF HEMOLYSATES FROM NORMAL ADULT AND NEWBORN SUBJECTS; BENZIDINE-NITROPRUSSIDE STAIN. The second half of the gel shown in Figure 2, reversed left to right in printing so that the tracks may be compared directly. Only $\mathrm{Hb} \mathrm{A}, \mathrm{F}, \mathrm{A}_{2}$ and NHP zone III give a positive reaction. 
TABLE II

Comparison between adult and fetal blood in regard to width and staining intensity of the zones

\begin{tabular}{|c|c|c|c|c|}
\hline \multirow{2}{*}{$\begin{array}{l}\text { Protein } \\
\text { zone }\end{array}$} & \multicolumn{2}{|c|}{ Width of zone } & \multicolumn{2}{|c|}{$\begin{array}{l}\text { Intensity of staining } \\
\text { with amido-black }\end{array}$} \\
\hline & Adult & Fetal & Adult & Fetal \\
\hline I & & & + & ++ \\
\hline $\begin{array}{l}\text { II } \\
\text { III }\end{array}$ & & & & $+{ }_{+}^{+}$ \\
\hline $\begin{array}{l}\text { IV } \\
A_{2}\end{array}$ & & & $\begin{array}{l}++ \\
++\end{array}$ & \\
\hline$A_{1}$ & $++t$ & -++ & +++ & ++++ \\
\hline
\end{tabular}

* Not observed in all specimens.

Only zone III of the NHP zones released gas bubbles on the addition of 3 per cent hydrogen peroxide to the gel. The area covered by the small gas bubbles corresponded exactly to the area of zone III as determined with either the amido-black stain or the benzidine-nitroprusside reagent.

No significant variation in the above pattern was observed from individual to individual or in the given subject from time to time.

The pattern of hemolysates prepared from the umbilical cord blood of 10 newborn infants was qualitatively similar to that of the adult subjects. However, certain differences were observed in the intensity of staining with amido-black (Table II), presumably indicating quantitative differences in the concentration of the proteins. NHP zones II and IV were greatly reduced in their intensity of stain, compared with the result in adults (Figure 2), and frequently zone II was barely visible. On the other hand, NHP zone III was as dark, or darker, than in samples from adults, while NHP zone I appeared as in the adult. The $\mathrm{A}_{2}$ hemoglobin zone was reduced in intensity of staining, in keeping with the reported low level of this component in the newborn; this reduction was similar in degree to that of the adjoining NHP zone IV.

Further studies characterizing the NHP zones. Electrophoresis of hemolysates after various chemical and physical treatments, electrophoresis of "purified" red cell enzymes, and enzyme assays were performed to assist in identifying or characterizing the NHP zones (Tables III, IV).

NHP zone I. Constituents of this zone were not identified but it could be separated from the native hemolysate by the procedure outlined by Moskowitz and colleagues (23) for the separation of $S$ protein. In addition, zone I proteins were found to be precipitated together with hemoglobin by the chloroform-ethanol reagent (26) and by exposure to alkali (24). NHP-I was readily eluted from IRC-50 (20) and was not adsorbed onto carboxymethyl cellulose (18) but was adsorbed onto diethylaminoethyl cellulose (19). Differential adsorption with these substituted celluloses afforded a means of separating zone I proteins from the hemoglobin of hemolysates.

NHP zone II. Constituents of this zone were not identified. In contrast to the protein(s) of zone I, NHP of zone II remained in the supernate after treatment of a hemolysate with alkali or the chloroform-ethanol reagent. It was ad-

TABLE III

Effect of certain chemical and physical agents on the erythrocytic NHP

\begin{tabular}{|c|c|c|c|c|c|}
\hline \multirow[b]{2}{*}{ Agent and reference } & \multicolumn{5}{|c|}{$\begin{array}{l}\text { Protein zones demonstrable in hemolysate } \\
\text { after specified treatment }\end{array}$} \\
\hline & $I$ & II & III & IV & $\mathrm{Hb}$ \\
\hline Chloroform-ethanol (26) & no & yes & no & yes & no \\
\hline $\begin{array}{l}\text { Potassium hydroxide, } \\
\text { pH } 12.7,2 \text { min }(24)\end{array}$ & no & yes & no & yes & no \\
\hline $\begin{array}{l}\text { Carboxymethyl cellulose, } \\
\text { phosphate buffered, } 0.01 \mathrm{M} \text {, } \\
\text { pH } 6.5 \text { (18) }\end{array}$ & yes & no & yes & yes & no \\
\hline $\begin{array}{l}\text { Diethylaminoethyl cellulose, } \\
\text { phosphate buffered, pH 7.0, } \\
0.003 \text { M (19) }\end{array}$ & no & yes & no & yes & yes \\
\hline $\begin{array}{l}\text { IRC-50, phosphate buffered, } \\
0.05 \mathrm{M}, \mathrm{pH} 6.92(20)^{*}\end{array}$ & yes & yes & yes & yes & no \\
\hline
\end{tabular}

* Tabulated data refer to eluate prior to release of hemoglobin from the resin. 
TABLE IV

Effect of certain chemical and physical agents on carbonic anhydrase and catalase enzymatic activity of hemolysates

\begin{tabular}{lcc}
\hline \hline & \multicolumn{2}{c}{$\begin{array}{c}\text { Enzymatic activity } \\
\text { demonstrable in } \\
\text { hemolysate after } \\
\text { specified treatment }\end{array}$} \\
\hline $\begin{array}{c}\text { Carbonic } \\
\text { anhydrase }\end{array}$ & Catalase \\
\hline Treatment and reference & yes & no \\
\hline $\begin{array}{l}\text { Chloroform-ethanol (26) } \\
\begin{array}{c}\text { Potassium hydroxide, } \\
\text { pH 12.7, 2 min (24) }\end{array}\end{array}$ & yes & no \\
$\begin{array}{c}\text { Carboxymethyl } \\
\text { cellulose (18) }\end{array}$ & yes & yes \\
$\begin{array}{c}\text { Diethylaminoethyl } \\
\text { cellulose (19) }\end{array}$ & yes & no \\
IRC-50 (20) & yes & yes
\end{tabular}

* Tabulated data refer to eluate prior to release of hemoglobin from the resin.

sorbed onto carboxymethyl cellulose but not onto diethylaminoethyl cellulose, and was readily eluted from IRC-50.

NHP zone III. As already noted, zone III was presumed to contain the heme enzyme, erythrocyte catalase, because of the release of gas over its area when hydrogen peroxide was applied to an unstained gel. Assays of eluates from all zones of the gel showed that significant catalase activity was limited to zone III (Table V) and that most of the catalase activity of a whole hemolysate prior to electrophoresis could be recovered from this zone of the gel. The following additional characteristics were noted: the protein of zone III was precipitated by the chloroform-ethanol reagent of Huennekens and co-workers (26) and by alkali (24); it was readily eluted from IRC-50 and was not adsorbed onto carboxymethyl cellulose; it was adsorbed by diethylaminoethyl cellulose, from which it could be subsequently eluted. Furthermore, NHP III protein was found to travel with $\mathrm{A}_{3}$ hemoglobin when hemolysates were subjected to electrophoresis on starch block, by means of the technic of Kunkel and colleagues (4).

NHP zone $I V$. The properties and enzymatic activity of this zone are those of erythrocyte carbonic anhydrase. Zone IV protein resisted precipitation by chloroform-ethanol $(26,27)$ or alkali (24), as does carbonic anhydrase (27), and was not adsorbed by carboxymethyl cellulose or diethylaminoethyl cellulose; it was readily eluted from IRC-50.
Assay of eluates of all zones of the gel revealed carbonic anhydrase enzyme activity only in zone IV (Table V). Furthermore, a refined concentrate of human erythrocyte carbonic anhydrase, ${ }^{2}$ prepared by calcium phosphate gel column chromatography and judged to be "pure" by ultracentrifugation and free electrophoresis, was composed almost entirely of material that corresponded to the mobility of NHP zone IV but contained very small quantities of two components having a greater anodal mobility than any of the NHP described above. The findings were the same when another human erythrocyte carbonic anhydrase concentrate, ${ }^{3}$ prepared by a different method, was studied.

After electrophoresis of a hemolysate on a starch block (4), the NHP eluted together with hemoglobin $\mathrm{A}_{2}$ and also obtained from the region between $A_{2}$ and the origin, proved to be NHP zone IV on our gels.

Catalase assays. The relationship between the intensity of staining of NHP zone III (Table II) and catalase activity was investigated. Whole

TABLE V

Assay of individual gel zones for catalase and carbonic anhydrase enzymatic activity *

\begin{tabular}{lcc}
\hline \hline Zone & Catalase, & $\begin{array}{c}\text { Carbonic } \\
\text { anhydrase }\end{array}$ \\
\hline NHP I & $\boldsymbol{K}_{\text {cat. }} \dagger$ & $\mathrm{sec}$ \\
NHP II & 0.00 & 145 \\
NHP III & 0.00 & 132 \\
NHP IV & 3.55 & 144 \\
Hb A & 0.00 & 56 \\
Hb A & 0.00 & 152 \\
& 0.15 & 149
\end{tabular}

* A hemolysate from a normal adult was used. After electrophoresis the unstained gel was sectioned into stated zones, using a single stained track from that gel as a guide. The liquid expressed from each section after freezing and thawing was assayed for enzymatic activity.

† Catalase assayed by method of Takahara and colleagues (21). $K_{\text {cat. }}$ for hemolysate, prior to electrophoresis, diluted 1:1,000 was $K_{\text {cat. }}=2.55$. Final dilution of samples submitted for assay, $1: 500$.

$\ddagger$ Method of Wilbur and Anderson (22). The figures record the time in seconds for the $\mathrm{pH}$ of veronal buffer to fall from 8.2 to 6.3 upon the addition of a standard quantity of carbon dioxide-saturated water; the blank value was 138 seconds; $0.1 \mathrm{ml}$ of $1: 75$ dilution of each eluate was used in a total reactant volume of $5.1 \mathrm{ml}$ to assay activity of each zone.

2 Generously provided by Dr. Egon Rickli of the Harvard Biological Labs.

3 Generously provided by Douglas Brown, Laboratory for the Study of Hereditary and Metabolic Disorders, Univ. of Utah. 


\begin{tabular}{ccc}
\multicolumn{3}{c}{$\begin{array}{c}\text { TABLE vI } \\
\text { Catalase activity in blood from } \\
\text { adult and newborn subjects }\end{array}$} \\
\hline & Adults & Newborn \\
\hline & 27 & 25 \\
$\begin{array}{l}\text { No. subjects } \\
\mathrm{K}_{\text {cat. }}{ }^{*}\end{array}$ & & \\
Range & $2.74-4.75$ & $1.58-3.61$ \\
Mean & $3.65 \dagger$ & $2.61 \dagger$ \\
SD & \pm 0.51 & \pm 0.52 \\
SE & \pm 0.10 & \pm 0.11 \\
\hline
\end{tabular}

${ }^{*} \mathrm{~K}_{\text {cat. }}=10^{3}\left(1 / t \cdot \log _{10} x_{0} / x_{t}\right)$, where $x_{0}=\mu$ moles $\mathrm{H}_{2} \mathrm{O}_{2}$ present at time zero; $x_{t}=\mu$ moles $\mathrm{H}_{2} \mathrm{O}_{2}$ remaining af ter the reaction has proceeded for $t$ seconds, where $t$ does not exceed 60.

$\dagger$ The probability that these means are from the same population is $<0.001$, as judged by the $t$ test $(41)$.

blood from newborn subjects was found to have less catalase activity per unit hemoglobin concentration than had blood from adult subjects (Table VI). This observation confirms the results of Jones and McCance (28) who employed a different method for assay. An earlier study by other workers (29) reported the converse. In a review of the subject (30) this discrepancy was attributed to technical differences, neither finding being favored.

\section{DISCUSSION}

Four nonhemoglobin proteins (NHP) have been repeatedly separated from one another and from the hemoglobins by electrophoresis despite the preponderance of hemoglobin in hemolysates. On some occasions two additional NHP were separated. In our experience a better result is afforded by the method described here than in systems buffered with phosphate at $\mathrm{pH} 6.5$ (6). On a single gel the NHP of eight different hemolysates may be studied qualitatively and semiquantitative assessments can be made. At the same time, electrophoretically abnormal hemoglobins may be detected and significant alterations in the concentration of the normal minor hemoglobin component, $\mathrm{A}_{2}$, may also be noted. This method may further be used to judge the purity of enzymes "isolated" from erythrocytes. Thus, an erythrocyte carbonic anhydrase preparation ${ }^{2}$ (judged to be "pure" by the criteria of ultracentrifugation and free electrophoresis) was found to contain, in addition to the principal component (NHP zone IV), other NHP in distinct zones of greater anodal mobility. This observa- tion is in agreement with the report of Rickli (31).

For several reasons it is unlikely that the NHP zones reported here represent denatured hemoglobin or globin, or other artifacts. First, all but one of the zones are benzidine-negative. Second, the electrophoretic migration of heme-free globin in no way resembles that of these NHP zones. Third, the only benzidine-positive NHP zone has been identified as containing the heme-enzyme, catalase, whereas one of the benzidine-negative zones has been identified as containing carbonic anhydrase. Fourth, all of these NHP have a lesser anodal mobility than has even the slowest of the hemoglobins, hemoglobin C. Finally, we do not believe that the NHP zones are artifacts of the $\mathrm{pH}$ selected for these studies. Although better separation of the NHP was afforded at $\mathrm{pH} 9.5$ than at the more conventional value of 8.6, increments in $\mathrm{pH}$ from the latter value did not produce an abrupt change in the electrophoretic pattern until a $\mathrm{pH}$ of 10.0 was reached, whereupon discrete protein zones were no longer formed. A hemolysate first equilibrated at $\mathrm{pH}$ 9.5 and then subjected to electrophoresis at $\mathrm{pH}$ 8.6 compared exactly with a portion of the same hemolysate not previously exposed to the higher $\mathrm{pH}$ but analyzed on the same gel. Also in support of our view, that these components are native to the erythrocyte, is the report of Rose and colleagues (32) of the separation of six to eight distinct constituents from hemolysates, by the use of immunoelectrophoretic analysis.

We have identified NHP zone IV as containing the erythrocytic carbonic anhydrase on the basis of assays for this enzymatic activity in the various zones of the gels (Table V) and by comparison with the migration of a refined preparation of erythrocytic carbonic anhydrase subjected to electrophoresis under the same conditions. In addition to these properties other observations concerning NHP IV are consistent with knowledge of carbonic anhydrase; namely, the stability of the latter at alkaline $\mathrm{pH}$ (27) and on exposure to chloroform-ethanol (27) and its relative reduction in erythrocytes of the newborn as compared with those of adults $(28,33)$.

Since NHP IV is present in higher concentration in adult erythrocytes than is any other NHP, and since we have readily demonstrated it under 
conditions which failed to demonstrate all of the other NHP, it seems probable that NHP zone IV corresponds to the NHP occasionally noted by other investigators in electrophoretic studies of hemolysates. There seems to be little doubt that the unidentified component, termed " $\mathrm{X}_{1}$ ", thoroughly studied by Derrien and Laurent, and their associates $(3,24,34-37)$ corresponds to the NHP zone IV of our studies. The characteristics detailed by those authors correspond to those of NHP zone IV, except that " $\mathrm{X}_{1}$ " was not studied for carbonic anhydrase activity by Derrien and his co-workers. Although not identified in a positive sense, the amino acid composition of " $\mathrm{X}_{1}$ " was sufficiently characterized to distinguish it from the hemoglobins A and F (34).

The identification of NHP zone III with erythrocytic catalase is based upon 1) liberation of gas from hydrogen peroxide by this zone alone; 2) limitation of significant catalatic activity, determined by direct assay of eluates of the gel, to this zone; and 3) the demonstration of peroxidatic activity in NHP zone III when the hydrogen peroxide concentration was kept sufficiently low, a fact consistent with the known behavior of catalase under such conditions (38).

Generally, NHP zone III stained more darkly in hemolysates from newborn subjects than from adult subjects, suggesting a higher concentration of catalase in the former. However, on direct assay we found the catalase activity to be lower in newborn than in the adult (Table VI). This paradoxical situation may be explained by a reduction in the catalase content of erythrocytes of the newborn, compared with the adult, together with the presence of a NHP in zone III in addition to catalase. An alternative and simpler explanation might be that the catalase in erythrocytes of the newborn has a lower specific activity than that of adults but is present in higher concentration, the latter inadequate to yield a net activity equal to that of adults. In the only reported occurrences of hypocatalasemia in adults (21), a decrease in the enzymatic activity was noted, but neither qualitative nor quantitative studies of the enzyme protein were reported.

Although the NHP of zone II have not been identified, on the basis of the information given in this report one may speculate that one or more of the enzymes known to remain in the super- nate after chloroform-ethanol treatment of hemolysates-namely, erythrocyte phosphoglucose isomerase (39), methemoglobin reductase (26) and, possibly, glutathione peroxidase (40), among others-may be present.

The apparent similarity between NHP zone I and the $S$ protein described by Moskowitz and colleagues (23) is of interest, but we have as yet found no information concerning its biological function or chemical nature.

\section{SUMMARY}

1. A method is described for electrophoresis of hemolysates on starch gel, using a Tris-citrateborate buffer system at $\mathrm{pH}$ 9.5. By this method a clear separation of six nonhemoglobin protein (NHP) zones may be achieved. Each of the NHP zones has characteristic appearance and properties, and all move more slowly toward the anode than do normal or abnormal hemoglobins.

2. NHP zone III contains the erythrocytic catalase and NHP zone IV contains erythrocytic carbonic anhydrase. The identity and functions of the proteins in the other zones are not yet known.

3. Umbilical cord blood differs from normal adult blood in giving an increased staining reaction of NHP zone III and a decreased staining of NHP zones II and IV and by having the well known lower quantity of the minor hemoglobin component, $\mathrm{A}_{2}$.

4. The described technic may be applied to the study of the purity of enzymatic preparations isolated from erythrocytes and to the study of erythrocytes with the object of detecting qualitative or quantitative alterations in enzymes or other NHP constituents in disease.

\section{ACKNOWLEDGMENTS}

Mrs. Janet Anderson provided valuable technical assistance. We are grateful to Dr. Stanley J. Altman for providing the specimens of umbilical cord blood.

\section{REFERENCES}

1. Stern, K. G., Reiner, M., and Silber, R. H. On the electrophoretic pattern of red blood cell proteins; preliminary study. J. biol. Chem. 1945, 161, 731.

2. Berry, E. R., and Chanutin, A. Electrophoretic studies of red cell extracts of stored blood. J. clin. Invest. 1957, 36, 225. 
3. Derrien, Y., Laurent, G., and Borgomano, M. Sur une protéine accompagnant l'hémoglobine de l'homme adulte et sa concentration dans la fraction alcalino-résistante isolée de cette dernière. C. R. Acad. Sci. (Paris) 1956, 242, 1538.

4. Kunkel, H. G., Ceppellini, R., Müller-Eberhard, U., and Wolf, J. Observations on the minor basic hemoglobin component in the blood of normal individuals and patients with thalassemia. J. clin. Invest. 1957, 36, 1615.

5. Labie, D., Rosa, J., Dreyfus, J.-C., and Schapira, G. Etude de l'hémoglobine $\mathrm{A}_{2}$ du sujet normal et au cours des différentes formes de thalassémie, par l'électrophorèse à travers gel d'amidon. Rev. franç. Et. clin. biol. 1958, 3, 481.

6. Fessas, P., and Mastrokalos, N. Demonstration of small components in red cell haemolysates by starch-gel electrophoresis. Nature (Lond.) 1959, 183, 1261.

7. Mehta, S. R., and Jensen, W. N. Haptoglobins in haemoglobinopathy: A genetic and clinical study. Brit. J. Haemat. 1960, 6, 250.

8. Yakulis, V. J., Heller, P., Josephson, A. M., and Singer, L. Rapid demonstration of $A_{2}$ hemoglobin by means of agar gel electrophoresis. Amer. J. clin. Path. 1960, 34, 28.

9. Markowitz, H., Hill, A. S., Jr., Cartwright, G. E., and Wintrobe, M. M. The protein "profile" of human erythrocytes. Fed. Proc. 1961, 20, 63.

10. Smithies, O. Zone electrophoresis in starch gels: Group variations in the serum proteins of normal human adults. Biochem. J. 1955, 61, 629.

11. Smithies, O. An improved procedure for starchgel electrophoresis: Further variations in the serum proteins of normal individuals. Biochem. J. 1959, 71, 585.

12. Haut, A., Tudhope, G. R., Cartwright, G. E., and Wintrobe, M. M. Electrophoretic separation of four erythrocytic proteins from hemoglobins. Clin. Res. 1961, 9, 92.

13. Drabkin, D. L. Spectrophotometric studies. XIV. The crystallographic and optical properties of the hemoglobin of man in comparison with those of other species. J. biol. Chem. 1946, 164, 703.

14. Poulik, M. D. Starch gel electrophoresis in a discontinuous system of buffers. Nature (Lond.) 1957, 180, 1477.

15. de Grouchy, J. Utilisation d'un système tampon discontinu au cours de l'électrophorèse des hémoglobines à travers gel d'amidon. Rev. franç. Et. clin. biol. 1958, 3, 877.

16. Aronsson, T., and Grönwall, A. Improved separation of serum proteins in paper electrophoresis: A new electrophoresis buffer. Scand. J. clin. Lab. Invest. 1957, 9, 338.

17. Goldberg, C. A. J. A new method for starch gel electrophoresis of human hemoglobins, with special reference to the determination of hemoglobin $A_{2}$. Clin. Chem. 1958, 4, 484.
18. Huisman, T. H., and Meyering, C. A. Studies on the heterogeneity of hemoglobin. I. The heterogeneity of different human hemoglobin types in carboxymethylcellulose and in Amberlite IRC-50 chromatography: Qualitative aspects. Clin. chim. Acta 1960, 5, 103.

19. Hennessey, M. A., Haffner, A. M., and Gabrio, B. W. The separation of erythrocyte enzymes from hemoglobin. Fed. Proc. 1960, 19, 65.

20. Allen, D. W., Schroeder, W. A., and Balog, J. Observations on the chromatographic heterogeneity of normal adult and fetal human hemoglobin: A study of the effects of crystallization and chromatography on the heterogeneity and isoleucine content. J. Amer. chem. Soc. 1958, 80, 1628.

21. Takahara, S., Hamilton, H. B., Neel, J. V., Kobara, T. Y., Ogura, Y., and Nishimura, E. T. Hypocatalasemia: A new genetic carrier state. J. clin. Invest. 1960, 39, 610.

22. Wilbur, K. M., and Anderson, N. G. Electrometric and colorimetric determination of carbonic anhydrase. J. biol. Chem. 1948, 176, 147.

23. Moskowitz, M., Dandliker, W. B., Calvin, M., and Evans, R. S. Studies on the antigens of human red cells. I. The separation from human erythrocytes of a water soluble fraction containing the $\mathrm{Rh}, \mathrm{A}$ and B factors. J. Immunol. 1950, 65, 383.

24. Derrien, Y., Laurent, G., and Roques, M. Recherches sur la fraction alcalinorésistante de l'hémoglobine de l'homme adulte normale. Arch. Sci. biol. (Bologna) 1955, 39, 650.

25. Tsuchihashi, M. Zur Kenntnis der Blutkatalase. Biochem. Z. 1923, 140, 63.

26. Huennekens, F. M., Liu, L., Myers, H. A. P. and Gabrio, B. W. Erythrocyte metabolism. III. Oxidation of glucose. J. biol. Chem. 1957, 227, 253.

27. Keilin, D., and Mann, T. Carbonic anhydrase. Purification and nature of the enzyme. Biochem. J. 1940, 34, 1163.

28. Jones, P. E. H., and McCance, R. A. Enzyme activities in the blood of infants and adults. Biochem. J. 1949, 45, 464.

29. Anselmino, K. J., and Hoffmann, F. Über den Glutathion- und Katalasegehalt des fetalen Blutes und seine Bedeutung für die Sauerstoffversorgung der Frucht. Arch. Gynäk. 1931, 143, 505 (cited by Jones and McCance, Ref. 28).

30. Driscoll, S. G., and Hsia, D. Y.-Y. The development of enzyme systems during early infancy. Pediatrics 1958, 22, 785.

31. Rickli, E. Carbonic anhydrase from human erythrocytes. Fed. Proc. 1961, 20, 241.

32. Rose, N., Peetoom, F., Ruddy, S., Micheli, A., and Grabar, P. Etude immunochimique des hémolysats des globules rouges humains. 1. Principaux constituants antigéniques. Ann. Inst. Pasteur 1960, 98, 70.

33. Vallee, B. L., and Altschule, M. D. Zinc in the mammalian organism, with particular reference to carbonic anhydrase. Physiol. Rev. 1949, 29, 370. 
34. Laurent, G., Borgomano, M., and Derrien, Y. Caractérisation chimique de la protéine $\mathrm{X}_{1}$ accompagnant l'hémoglobine humaine dans ses préparations. C. R. Soc. Biol. (Paris) 1958, 152, 976.

35. Laurent, G., Depieds, J., and Derrien, Y. Origine endoglobulaire des protéines accompagnant l'hémoglobine humaine dans ses préparations. C. R. Soc. Biol. (Paris) 1958, 152, 113.

36. Depieds, R., and Laurent, G. Electrophorèse sur gélose de la protéine $X_{1}$ isolée des préparations d'hémoglobine humaine. C. R. Soc. Biol. (Paris) 1958, 152, 1552.

37. Derrien, Y., Laurent, G., and Borgomano, M. Détection de la protéine d'accompagnement $\mathrm{X}_{1}$ dans l'hémoglobine du nouveau-né. C. R. Soc. Biol. (Paris) 1959, 153, 792.

38. Maehly, A. C., and Chance, B. The assay of catalases and peroxidases in Methods of Biochemical Analysis, D. Glick, Ed. New York, Interscience, 1954, vol. 1, p. 357.

39. Tsuboi, K. K., Estrada, J., and Hudson, P. B. Enzymes of the human erythrocyte. IV. Phosphoglucose isomerase, purification and properties. $\mathrm{J}$. biol. Chem. 1958, 231, 19.

40. Mills, G. C. The purification and properties of glutathione peroxidase of erythrocytes. J. biol. Chem. 1959, 234, 502.

41. Croxton, F. E. Elementary Statistics with Applications in Medicine. New York, Prentice-Hall, 1953. 